\title{
DAYA SERAP DAN KARAKTERISASI ARANG AKTIF TULANG SAPI YANG TERAKTIVASI NATRIUM KARBONAT TERHADAP LOGAM TEMBAGA
}

\author{
Popy Previanti ${ }^{\mathrm{a}}$, Hena Sugiani ${ }^{\mathrm{a}}, \mathrm{Uji}$ Pratomo $^{\mathrm{b} *}, \&$ Sukrido $^{\mathrm{a}}$ \\ a Jurusan Kimia, Universitas Ahmad Yani \\ J1. Terusan Jendral Sudirman, PO Box 148 Cimahi, Jawa Barat, Indonesia \\ ${ }^{\mathrm{b}}$ Departemen Kimia, Fakultas Matematika dan Ilmu Pengetahuan Alam, Universitas Padjadjaran \\ Jl. Raya Bandung-Sumedang km. 21 Jatinangor, Sumedang 45363, Jawa Barat - Indonesia \\ *Alamat korespondensi: u.pratomo@unpad.ac.id
}

\begin{abstract}
Abstrak: Pemanfaatan limbah tulang sapi dirasa belum optimal. Padahal, jika dimanfaatkan dengan baik untuk kepentingan ilmu pengetahuan, akan berdampak positif mengingat konsumsi daging sapi pada kehidupan seharihari cukup besar. Salah satu pemanfaatannya adalah sebagai adsorben terhadap logam berat yang berdampak buruk bagi lingkungan. Tujuan dari penelitian ini untuk mengetahui kondisi optimum, karakterisasi, dan kandungan dari arang aktif tulang sapi terhadap logam tembaga yang telah teraktivasi natrium karbonat. Metode yang digunakan adalah aktivasi arang sapi menggunakan natrium karbonat, karakterisasi serta pengukuran menggunakan instrument kimia. Hasil karakterisasi kondisi optimum arang aktif pada ukuran partikel 120 mesh, aktivator 5\%, waktu kontak aktivasi 24 jam, suhu 800 0C, dan variasi adsorbat dan adsorben 1 g. Hasil efisiensi adsorpsi terhadap logam tembaga sebesar $99,65 \%$.
\end{abstract}

Kata kunci: Adsorpsi, Arang aktif, Logam tembaga, Natrium karbonat

\section{PENDAHULUAN}

Dalam keseharian di negara Indonesia pada era industrialisasi ini, masih banyak bahan dasar yang murah dan mudah didapat yang belum dimanfaatkan untuk diolah menjadi produk yang lebih potensial dan berdaya guna tinggi, salah satunya yaitu tulang. Tulang yang digunakan dalam penelitian ini yaitu tulang sapi. Komposisi tulang sapi terdiri atas 93\% hidroksiapatit (Ca10(PO4)6(OH)2) dan 7\% $\beta$ tricalcium phosphate (Ca3(PO4)2, $\beta$-TCP) (Ooi et al.,2007). Tulang sapi dapat diasumsikan sebagai sampah atau sisa makanan yang sampai saat ini pemanfaatananya masih minim dilakukan (Darmayanto, 2009). Handayani dkk (2015) menyatakan bahwa tingginya konsumsi daging sapi menyebabkan tinggi pula limbah tulang sapi yang dihasilkan dengan pemanfaatan yang belum begitu optimal.

Dalam penelitian ini, tulang sapi digunakan sebagai adsorben untuk logam tembaga. Adsorben adalah zat yang mempunyai sifat mengikat molekul pada permukaan dan sifat ini sangat menonjol pada padatan berpori (Sukardjo, 2002). Terlebih dahulu tulang sapi diubah menjadi arang aktif melalui proses karbonisasi dan aktivasi yang kemudian dilakukan proses penyerapan terhadap logam tembaga. Tembaga bersifat racun, tahan lama, dan dapat memasuki tubuh atau organ serta tinggal menetap didalam tubuh dalam jangka waktu yang lama. Tembaga berasal dari bahan buangan pada industri galangan kapal, industri pengolahan kAntika, dan limbah domestik. Kadar tembaga pada limbah, melebihi nilai baku mutu yang ditetapkan oleh Keputusan Menteri Negara Lingkungan Hidup tentang Baku Mutu Air Limbah Bagi Usaha dan atau Kegiatan Pertambangan Bijih Emas dan atau
Tembaga yaitu sebesar 2 ppm (SNI 06-6989-6-2004). Dalam hal ini logam berat tersebut mempunyai sifat toksik dan berbahaya terhadap manusia dan lingkungan.

Untuk mendapatkan arang aktif dengan adsorpsi terbaik terhadap logam tembaga, maka dalam penelitian ini dilakukan penentuan kondisi optimum untuk ukuran partikel, aktivator, waktu kontak aktivasi, suhu, dan variasi antara adsorben dan adsorbat dari arang aktif dengan Spektroskopi Serapan Atom (SSA). Sedangkan untuk mengetahui morfologi permukaan dan kandungan dari arang aktif dilakukan pengujian menggunakan Scanning Electron Microscopy (SEM).

\section{BAHAN DAN METODE \\ Bahan}

Bahan yang digunakan adalah akuades, indikator universal (merck), kertas saring Whatman 42, larutan amilum $1 \%$, larutan iodium $\left(\mathrm{I}_{2}\right)$, larutan natrium karbonat $\left(\mathrm{Na}_{2} \mathrm{CO}_{3}\right)$, larutan natrium tiosulfat $\left(\mathrm{Na}_{2} \mathrm{~S}_{2} \mathrm{O}_{3}\right)$, larutan tembaga $(\mathrm{Cu})$, plastik wrap, dan tulang sapi.

Alat yang digunakan adalah alat-alat gelas yang umum digunakan di Laboratorium, ayakan ukuran (60, 80, 100, dan 120 mesh), cawan porselen, desikator, furnace (Heraem), gerinda potong (maktec), kaca arloji, klem, magnetic stirrer, mortir, neraca analitik, oven (carbolite), pipet tetes, Scanning Electron Microscopy (SEM) (Hitachi TM 3000), spatula, Spektrofotometer Serapan Atom (SSA), dan statif.

\section{Metode}

Pengambilan dan Pengolahan Sampel 
Sampel yang digunakan adalah limbah tulang sapi yang telah melalui proses pemasakan, diambil dari salah satu penjual mie kocok di kota Bandung. Sampel dicuci bersih dan dipisahkan dari dagingnya, kemudian dikeringkan dibawah sinar matahari. Setelah kering tulang sapi dipotong kecil-kecil menggunakan alat gerinda potong, dan sampel siap dikarbonisasi.

\section{Proses Karbonisasi}

Tulang sapi yang telah dibersihkan dan dikeringkan kemudian ditimbang sebanyak $1,50 \mathrm{~kg}$. Sampel dimasukan ke dalam cawan porselen secara bertahap. Kemudian dimasukan kedalam furnace pada suhu $800^{\circ} \mathrm{C}$ selama \pm 2 jam. Didiamkan hingga arang tulang sapi dingin, kemudian digerus dan diayak.

\section{Penentuan Kondisi Optimum Ukuran Partikel}

Aktivasi arang tulang sapi dilakukan dengan cara, tulang sapi yang telah dikarbonisasi menjadi arang, digerus hingga halus dan diayak lolos ukuran 60, 80, 100, dan 120 mesh hingga didapatkan serbuk arang dari tiap ukuran mesh. Diambil masing-masing $10,00 \mathrm{~g}$, kemudian direndam dengan $100 \mathrm{~mL}$ $\mathrm{Na} 2 \mathrm{CO} 30,1 \mathrm{~N}$ kedalam gelas kimia $250 \mathrm{~mL}$, didiamkan selama 24 jam. Kemudian disaring dengan kertas Whatman 42, lalu dikeringkan dalam oven $100^{\circ} \mathrm{C}$ selama 40 menit dan dikalsinasi dalam furnace pada suhu $800^{\circ} \mathrm{C}$ selama 40 menit. Selanjutnya didinginkan dan dicuci dengan akuades berulang kali hingga $\mathrm{pH}$ netral, kemudian dikeringkan dalam oven pada suhu $105^{\circ} \mathrm{C}$ dan dimasukan ke dalam desikator selama 30 menit.

\section{Penentuan Kondisi Optimum Aktivator}

Kondisi optimum ukuran partikel arang aktif tulang sapi, diambil masing-masing $10,00 \mathrm{~g}$, kemudian direndam dengan $100 \mathrm{~mL} \mathrm{Na}_{2} \mathrm{CO}_{3} 0,1 \mathrm{~N}$ dengan variasi 0,$0 ; 2,5 ; 5,0 ; 7,5$; dan $10 \%$ kedalam gelas kimia $250 \mathrm{~mL}$, didiamkan selama 24 jam. Kemudian disaring dengan kertas Whatman 42, lalu dikeringkan dalam oven $100^{\circ} \mathrm{C}$ selama 40 menit dan dikalsinasi dalam furnace pada suhu $800^{\circ} \mathrm{C}$ selama 40 menit. Selanjutnya didinginkan dan dicuci dengan akuades berulang kali hingga $\mathrm{pH}$ netral, kemudian dikeringkan dalam oven pada suhu $105^{\circ} \mathrm{C}$ dan dimasukan ke dalam desikator selama 30 menit.

\section{Penentuan Kondisi Optimum Waktu Kontak Aktivasi}

Kondisi optimum ukuran partikel arang aktif tulang sapi, diambil masing-masing 10,00 g, kemudian direndam dengan $100 \mathrm{~mL}$ aktivator $\mathrm{Na}_{2} \mathrm{CO}_{3} 0,1 \mathrm{~N}$ pada kondisi optimum dalam gelas kimia $250 \mathrm{~mL}$, didiamkan selama 24 dan 48 jam. Kemudian disaring dengan kertas Whatman 42, lalu dikeringkan dalam oven $100^{\circ} \mathrm{C}$ selama 40 menit dan dikalsinasi dalam furnace pada suhu $800^{\circ} \mathrm{C}$ selama 40 menit. Selanjutnya didinginkan dan dicuci dengan akuades berulang kali hingga $\mathrm{pH}$ netral, kemudian dikeringkan dalam oven pada suhu $105^{\circ} \mathrm{C}$ dan dimasukan ke dalam desikator selama 30 menit.

\section{Penentuan Kondisi Optimum Suhu}

Kondisi optimum ukuran partikel arang aktif tulang sapi, diambil masing-masing 10,00 g, kemudian direndam dengan $100 \mathrm{~mL}$ aktivator $\mathrm{Na} 2 \mathrm{CO} 30,1 \mathrm{~N}$ pada kondisi optimum dalam gelas kimia $250 \mathrm{~mL}$ dengan waktu kontak optimum. Kemudian disaring dengan kertas Whatman 42, lalu dikeringkan dalam oven $100^{\circ} \mathrm{C}$ selama 40 menit dan dikalsinasi dalam furnace pada suhu 400, 600, dan $800^{\circ} \mathrm{C}$ selama 40 menit. Selanjutnya didinginkan dan dicuci dengan akuades berulang kali hingga $\mathrm{pH}$ netral, kemudian dikeringkan dalam oven pada suhu $105^{\circ} \mathrm{C}$ dan dimasukan ke dalam desikator selama 30 menit.

\section{Karakterisasi Arang Aktif \\ Kadar Air Arang Aktif}

Sebanyak 1,00 g arang aktif ditimbang dengan neraca analitik, kemudian dikeringkan dalam oven pada suhu $105^{\circ} \mathrm{C}$ hingga bobot konstan. Selanjutnya sampel dimasukkan kedalam desikator selama 15 menit, dan ditimbang hingga berat konstan. Prosedur diatas dilakukan secara bertahap untuk penentuan kondisi optimum ukuran partikel, aktivator, waktu kontak, suhu, dan variasi antara adsorben dan adsorbat dari arang aktif.

Kadar air $(\%)=\frac{\text { Berat penyusutan sampel }(\mathrm{g})}{\text { Berat sampel sebelum pemanasan }(\mathrm{g})} \times 100 \%$

\section{Kadar Abu Arang Aktif}

Sebanyak $1,00 \mathrm{~g}$ arang aktif dimasukkan kedalam cawan porselin. Kemudian dimasukkan ke dalam furnace pada suhu $805^{\circ} \mathrm{C}$ sampai terbentuk abu. Selanjutnya sampel dimasukkan kedalam desikator selama 15 menit, dan ditimbang hingga berat konstan. Prosedur diatas dilakukan secara bertahap untuk penentuan kondisi optimum ukuran partikel, aktivator, waktu kontak aktivasi, suhu, dan variasi antara adsorben dan adsorbat dari arang aktif.

Kadar abu $(\%)=\frac{\text { Berat abu total }(\mathrm{g})}{\text { Berat sampel }(\mathrm{g})} \times 100 \%$

\section{Daya Serap Terhadap Iodium}

Ditimbang sebanyak $1,00 \mathrm{~g}$ arang aktif dipanaskan dalam oven pada suhu $105^{\circ} \mathrm{C}$ selama 1 jam, kemudian didinginkan dalam desikator selama 30 menit. Setelah arang aktif dingin, diberi perlakuan dengan penambahan $100 \mathrm{~mL}$ larutan $\mathrm{I} 2$ 0,1 N diaduk selama 15 menit dan didiamkan selama 15 menit. Kemudian diambil $25 \mathrm{~mL}$ filtrat dan dilakukan proses titrasi dengan menggunakan larutan Na2S2O3 0,1 N hingga terbentuk warna kuning, jika warna kuning telah samar lakukan penambahan $1 \mathrm{~mL}$ larutan amilum $1 \%$ sebagai indikator. Untuk penentuan kondisi optimum antara adsorben dan adsorbat 
dilakukan dengan variasi 1,00; 1,50; dan 2,00 g arang aktif dengan prosedur yang sama seperti diatas. Prosedur diatas dilakukan secara bertahap untuk penentuan kondisi optimum ukuran partikel, aktivator, waktu kontak aktivasi, suhu, dan variasi antara adsorben dan adsorbat dari arang aktif.

$$
I=\frac{(\mathrm{V} 1 \mathrm{~N} 1-\mathrm{V} 2 \mathrm{~N} 2) \times 126,9 \times \mathrm{fp}}{\mathrm{W}}
$$

Keterangan :

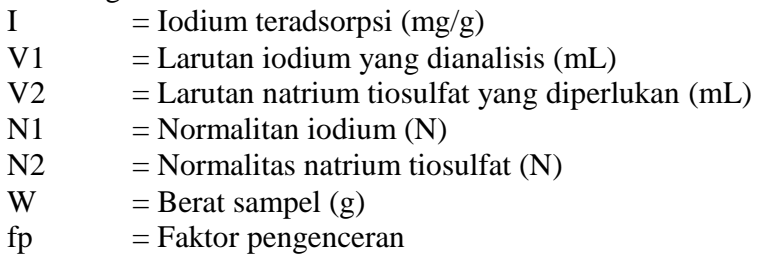

\section{HASIL DAN PEMBAHASAN}

Pembuatan arang tulang sapi diawali dengan proses pengeringan dibawah sinar matahari untuk menghilangkan air yang terkandung didalam sampel tulang sapi, yang sebelumnya telah dilakukan proses pencucian dan pemotongan bagian tulang sapi hingga kecil agar memudahkan dalam proses karbonisasi. Setelah proses pengeringan selesai, kemudian dilakukan proses karbonisasi. Proses karbonisasi adalah suatu proses dimana unsur oksigen dan hidrogen dihilangkan dari karbon dan akan menghasilkan kerangka karbon dengan kemurnian yang tinggi. Selanjutnya dilakukan proses aktivasi terhadap arang menggunakan aktivator natrium karbonat. Tujuan utama dari proses aktivasi adalah menambah atau mengembangkan volume pori dan memperbesar diameter pori yang telah terbentuk pada proses karbonisasi serta untuk membuat beberapa pori baru (Seranno el.all., 1996).

\section{Penentuan Kondisi Optimum Ukuran Partikel}

Hasil karakterisasi arang aktif yang paling optimum yaitu arang aktif dengan ukuran partikel 120 mesh, hal ini disebabkan pori-pori pada arang aktif relatif besar yaitu $125 \mu \mathrm{m}$.

Tabel 1. Data hasil karakterisasi arang aktif tulang sapi untuk kondisi optimum ukuran partikel

\begin{tabular}{cccccc}
\hline & & \multicolumn{4}{c}{ Ukuran partikel arang aktif tulang sapi } \\
\cline { 3 - 6 } No & Parameter & $\begin{array}{c}60 \\
\text { mesh }\end{array}$ & $\begin{array}{c}80 \\
\text { mesh }\end{array}$ & $\begin{array}{c}100 \\
\text { mesh }\end{array}$ & $\begin{array}{c}120 \\
\text { mesh }\end{array}$ \\
\hline 1 & $\begin{array}{c}\text { Kadar air } \\
(\%)\end{array}$ & 7,13 & 7,14 & 12,05 & 4,66 \\
2 & $\begin{array}{c}\text { Kadar } \\
\text { abu (\%) }\end{array}$ & 10,18 & 9,47 & 13,75 & 9,19 \\
3 & $\begin{array}{c}\text { Adsorpsi } \\
\text { iodium } \\
\text { (mg/g) }\end{array}$ & 39,92 & 46,97 & 49,11 & 59,94 \\
\hline
\end{tabular}

Pada penentuan ukuran partikel proses aktivasinya menggunakan natrium karbonat $10 \%$, dengan suhu aktivasi $800^{\circ} \mathrm{C}$, dan waktu kontak aktivasi $24 \mathrm{jam}$, hal ini mengacu pada penelitian
Handayani, dkk (2015). Kadar air tertinggi dimiliki oleh arang aktif dengan ukuran partikel 100 mesh sebesar 12,05\%. Terikatnya molekul air oleh aktivator akan meningkatkan kemampuan adsorpsi dari arang aktif tulang sapi. Kadar abu tertinggi dimiliki oleh arang aktif dengan ukuran partikel 100 mesh sebesar 13,75\%. Ini dapat disebabkan karena adanya kandungan bahan mineral yang terdapat di dalam bahan awal biomassa pembuat karbon (Sudrajat dalam Nailul Fauziah (2011)). Bahan mineral inilah yang kemudian akan membentuk menjadi senyawa abu apabila dilakukan proses oksidasi. Pengujian daya serap terhadap iodium bertujuan untuk mengetahui kemampuan arang aktif untuk menyerap larutan berwarna. Jika dilihat dari tabel 1 Tinggi rendahnya daya serap arang aktif terhadap iodium menunjukan jumlah mikropori yang terbentuk pada arang aktif. Semakin tinggi daya serap iodium maka semakin banyak mikropori yang terbentuk pada arang aktif.

\section{Penentuan Kondisi Optimum Aktivator}

Proses karakterisasi pada penentuan kondisi optimum aktivator, dilakukan dengan ukuran partikel arang 120 mesh, suhu pemanasan $800^{\circ} \mathrm{C}$ dan waktu kontak aktivasi 24 jam, dengan variasi aktivator $0,0 \% ; 2,5 \% ; 5,0 \% ; 7,5 \%$ dan $10 \%$.

Tabel 2. Data hasil karakterisasi arang aktif tulang sapi untuk kondisi optimum akivator

\begin{tabular}{ccccccc}
\hline No & Paramet & \multicolumn{5}{c}{ Konsentrasi aktivator natrium karbonat } \\
\cline { 3 - 7 } & er & $0,0 \%$ & $2,5 \%$ & $5,0 \%$ & $7,5 \%$ & $10 \%$ \\
\hline 1 & $\begin{array}{c}\text { Kadar } \\
\text { air (\%) }\end{array}$ & 8,83 & 10,97 & 6,50 & 1,82 & 2,47 \\
2 & $\begin{array}{c}\text { Kadar } \\
\text { abu (\%) } \\
\text { Adsorp } \\
\text { si }\end{array}$ & 3,03 & 5,29 & 1,33 & 1,39 & 1,44 \\
3 & $\begin{array}{c}\text { si } \\
\text { iodium } \\
\text { (mg/g) }\end{array}$ & 26,77 & 21,39 & 30,35 & 24,08 & 20,50 \\
\hline
\end{tabular}

Pada tabel 2 terlihat bahwa kondisi optimum yakni pada konsentrasi aktivator 5\%. Hal ini disebabkan pada konsentrasi 2,5\% kemampuan untuk membuka pori-pori arang aktif relatif masih sedikit, sehingga daya serap akan sedikit. Sedangkan pada konsentrasi 5\% telah mencapai keadaan optimum sehingga untuk membuka pori-pori arang akan lebih besar. Jika dibandingkan dengan konsentrasi 7,5\% dan $10 \%$ kemampuan serapannya berkurang hal ini dikarenakan konsentrasi aktivator yang tinggi akan menghasilkan banyak natrium oksida yang akan menutupi pori-pori dari arang aktif (Handayani, dkk., 2015).

\section{Penentuan Kondisi Optimum Waktu Kontak Aktivasi}

Pada penentuan kondisi optimum waktu kontak aktivasi dilakukan proses aktivasi terhadap arang aktif selama 24 jam dan 48 jam. 
Tabel 3. Data hasil karakterisasi arang aktif tulang sapi untuk kondisi optimum waktu kontak aktivas

\begin{tabular}{cccc}
\hline \multirow{2}{*}{ No } & Parameter & \multicolumn{2}{c}{$\begin{array}{c}\text { Waktu kontak } \\
\text { aktivasi }\end{array}$} \\
\cline { 3 - 4 } & & 24 jam & $\begin{array}{c}48 \\
\text { jam }\end{array}$ \\
\hline 1 & Kadar air (\%) & 6,00 & 6,33 \\
2 & Kadar abu (\%) & 4,36 & 8,23 \\
3 & Adsorpsi iodium (mg/g) & 30,17 & 30,07 \\
\hline
\end{tabular}

Jika dilihat pada tabel 3 hasil karakterisasi untuk waktu kontak aktivasi 24 jam dan 48 jam tidak memiliki perbedaan yang signifikan. Sehingga dalam penelitian ini digunakan waktu kontak 24 jam.

\section{Penentuan Kondisi Optimum Suhu}

Penentuan kondisi optimum suhu dilakukan dengan memvariasikan suhu yaitu 400, 600, dan $800^{\circ} \mathrm{C}$, dengan menggunakan ukuran partikel arang aktif 120 mesh, konsentrasi aktivator 5\%, dan waktu kontak aktivasi 24 jam.

Tabel 4. Data hasil karakterisasi arang aktif tulang sapi untuk kondisi optimum suhu

\begin{tabular}{ccccc}
\hline No & Parameter & \multicolumn{3}{c}{ Suhu } \\
\cline { 3 - 5 } & & $400^{\circ} \mathrm{C}$ & $600^{\circ} \mathrm{C}$ & $800^{\circ} \mathrm{C}$ \\
\hline 1 & Kadar air (\%) & 11,3 & 8,02 & 5,69 \\
2 & Kadar abu (\%) & 3,08 & 4,76 & 6,01 \\
3 & $\begin{array}{c}\text { Adsorpsi iodium } \\
(\mathrm{mg} / \mathrm{g})\end{array}$ & 37,94 & 34,74 & 40,37 \\
\hline
\end{tabular}

Kadar air ini mengalami penurunan seiring dengan naiknya suhu karbonisasi yang digunakan. Secara kimia air mulai mengalami perubahan fase menjadi gas pada saat telah mencapai titik didihnya, yakni pada suhu $100^{\circ} \mathrm{C}$. Pada titik tersebut, air bebas yang terikat pada karbon terlepas dan membentuk fase gas. Kadar air yang semakin tinggi akan menyebabkan daya serap karbon semakin berkurang. Dan nilai kadar abu bertambah seiring dengan naiknya suhu yang digunakan dalam proses karbonisasi. Penyerapan arang aktif yang rendah lebih disebabkan oleh masih banyaknya kontaminan yang masih menempel pada permukaan karbon aktif yang masih belum sempat menguap pada saat proses karboninsasi berlangsung.

\section{Penentuan Kondisi Optimum Variasi Antara Adsorbat dan Adsorben}

Pada penentuan kondisi optimum variasi antara adsorbat dan adsorben dilakukan pada karakterisasi arang aktif yaitu pada prosedur daya serap terhadap iodium. Dimana hanya pada arang aktifnya saja yang dilakukan variasi yaitu 1,00; 1,50; dan 2,00 g.

Daya adsorpsi tersebut dapat ditunjukkan dengan besarnya angka iodium yaitu angka yang menunjukkan seberapa besar adsorben dapat mengadsorpsi iodium. Semakin besar nilai angka iodium maka semakin besar pula daya adsorpsi dari adsorben. Penambahan larutan iodium berfungsi sebagai adsorbat yang akan diserap oleh karbon aktif sebagai adsorbennya. Terserapnya larutan iodium ditunjukkan dengan adanya pengurangan konsentrasi larutan iodium.Tabel 5 menunjukan nilai adsorpsi iodium pada variasi berat adsorben dan adsorbat.

Tabel 5. Data hasil karakterisasi arang aktif tulang sapi untuk kondisi optimum variasi antara adsorbat dan adsorben

\begin{tabular}{|c|c|c|c|c|}
\hline \multirow[t]{2}{*}{ No } & \multirow[t]{2}{*}{ Parameter } & \multicolumn{3}{|c|}{$\begin{array}{c}\begin{array}{c}\text { Variasi antara adsorbat dan } \\
\text { adsorben }\end{array} \\
\end{array}$} \\
\hline & & $1,00 \mathrm{~g}$ & $1,50 \mathrm{~g}$ & $2,00 \mathrm{~g}$ \\
\hline 1 & $\begin{array}{c}\text { Adsorpsi iodium } \\
(\mathrm{mg} / \mathrm{g})\end{array}$ & 72,35 & 35,95 & 16,49 \\
\hline
\end{tabular}

Penentuan Daya Adsorpsi Arang Tulang Sapi yang Telah Diaktivasi oleh Natrium Karbonat pada Kondisi Optimum

Setelah didapatkan arang aktif dalam kondisi optimum baik dari segi ukuran partikel, konsentrasi aktivator, waktu kontak aktivasi, suhu pemanasan, variasi antara adsorbat dan adsorben, maka dilakukan pengujian kembali dengan proses yang sama yaitu melalui tahap karakterisasi.

Tabel 6. Data hasil karakterisasi arang aktif tulang sapi yang telah diaktivasi oleh natrium karbonat pada kondisi optimum

\begin{tabular}{ccc}
\hline No & Parameter & Hasil \\
\hline 1 & Kadar air (\%) & 11,68 \\
2 & Kadar abu (\%) & 9,87 \\
3 & Adsorpsi iodium & 115,45 \\
\hline
\end{tabular}

Berdasarkan hasil pada tabel 6, bahwa arang tulang sapi yang telah diaktivasi dengan natrium karbonat memiliki kadar air sebesar $11,68 \%$, kadar abu sebesar $9,87 \%$ dan daya serap terhadap iodium sebesar $115,4536 \mathrm{mg} / \mathrm{g}$.

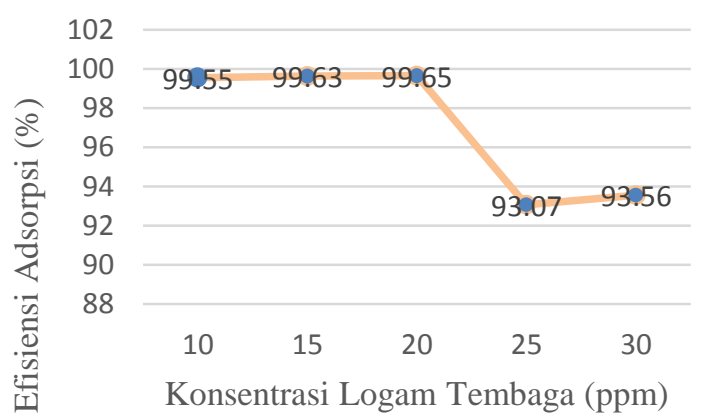

Gambar 1. Kurva hubungan antara efisiensi adsorpsi terhadap variasi konsentrasi logam tembaga setelah penentuan kondisi optimum ukuran partikel arang aktif 120 mesh, aktivator 5\%, waktu kontak aktivasi 24 jam, suhu 
$800^{\circ} \mathrm{C}$, variasi adsorbat dan adsorben $1 \mathrm{~g}$, dan waktu kontak terhadap logam tembaga selama 24 jam

Gambar 1 menunjukan bahwa pada konsentrasi 10 - 20 ppm menghasilkan kapasitas adsorpsi yang cenderung mengalami peningkatan penyerapan dengan selisih yang relatif kecil. Kondisi penyerapan optimum terjadi pada konsentrasi logam tembaga 20 ppm sebesar 99,65\%. Menurut Wijayanti (2009) bila permukaan telah jenuh atau mendekati jenuh terhadap adsorbat maka dapat terjadi dua hal, yaitu yang pertama terbentuk lapisan adsorpsi kedua dan seterusnya di atas adsorbat yang telah terikat di permukaan, gejala ini disebut adsorpsi multilayer, sedangkan yang kedua tidak terbentuk lapisan kedua dan seterusnya sehingga adsorbat yang belum teradsorpsi berdifusi keluar pori dan kembali ke arus fluida.

Berdasarkan efisiensi adsorpsi logam tembaga yang didapat sebesar 99,65\%, hasil tersebut dapat dikatakan bahwa arang aktif dari tulang sapi dapat dijadikan sebagai adsorben logam tembaga.

\section{Karakterisasi Arang Aktif Tulang Sapi dengan SEM-EDX}

Adanya perbedaan morfologi permukaan dari arang aktif tulang sapi berbentuk tidak beraturan (amorf), dapat dilihat pada gambar 1 dimana bagian (a) arang aktif tulang sapi dengan pembesaran 600 kali yang memiliki diameter sebesar $81,6 \mu \mathrm{m}$, hasil tersebut arang aktif belum dilakukan perendaman dengan logam tembaga, sehingga pori-pori masih belum tertutupi oleh apapun. Sedangkan untuk bagian (b) terlihat bahwa pori-pori permukaan arang aktif tulang sapi telah dipenuhi oleh logam tembaga, dengan pembesaran 6000 kali yang menghasilkan diameter sebesar $24,9 \mu \mathrm{m}$.

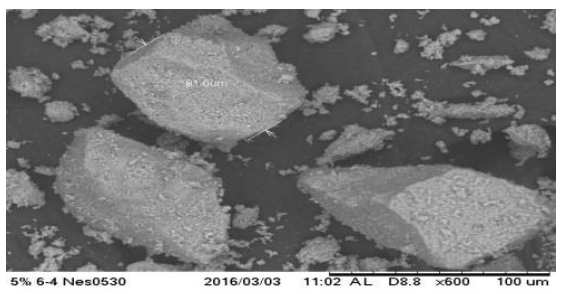

(a)

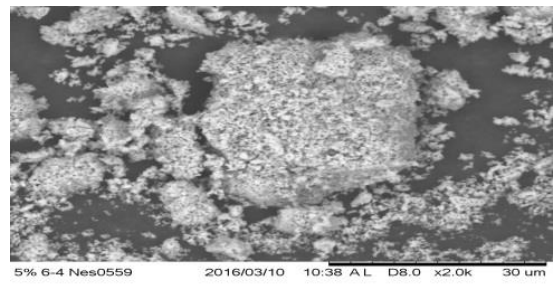

(b)

Gambar 2 (a) Hasil analisis arang aktif tulang sapi sebelum perendaman logam tembaga dengan pembesaran 600 kali dan 1000 kali (b) setelah perendaman logam tembaga dengan pembesarana 2000 kali dan 6000 kali menggunakan alat SEM-EDX
Tabel 7. Kandungan arang aktif tulang sapi menggunakan SEM-EDX

\begin{tabular}{cc}
\hline Element & Atomic \% \\
\hline Carbon & 22.029 \\
Oxygen & 52.752 \\
Magnesium & 0.366 \\
Aluminum & 0.631 \\
Phosphorus & 8.862 \\
Calcium & 15.360 \\
Copper & 0,823 \\
\hline
\end{tabular}

\section{KESIMPULAN}

Arang aktif tulang sapi berpotensi untuk dijadikan sebagai adsorben pada logam tembaga. Logam tembaga yang dapat teradsorpsi oleh arang aktif tulang sapi yang telah teraktivasi natrium karbonat yaitu sebesar 99,65\%. Kondisi optimum arang aktif untuk penyerapan logam tembaga terjadi pada ukuran partikel 120 mesh, konsentrasi kativator $5 \%$, waktu kontak aktivasi 24 jam, suhu pemanasan $800^{\circ} \mathrm{C}$, dan variasi antara adsorbat dan adsorben yaitu pada 1 gram. Kandungan arang aktif yang teraktivasi natrium karbonat dari tulang sapi mengandung karbon, oksigen, alumunium, kalsium, dan tembaga.

\section{DAFTAR PUSTAKA}

Handayani, A., Bali, S., \& Itnawita. (2015). Potensi Arang Aktif Dari Tulang Kerbau Sebagai Adsorben Ion Besi, Timbal, Sulfat Dan Klorida Dalam Larutan. JOM FMIPA , 2 (1), 47-55.

Antika, A., Anita, S., \& Hanifah, T.A. (2015). Potensi Arang Aktif Tulang Sapi Sebagai Adsorben Ion Timbal, Kadmium, Nitrat Dan Klorida Dalam Larutan. JOM FMIPA , 2 (1), 90-99.

Budiono, A. (2010). Pengaruh Aktivasi Arang Tempurung Kelapa dengan Asam Sulfat dan Asam Fosfat untuk Adsorpsi Fenol. Skripsi. Universitas Diponegoro. Semarang.

Darmayanto. (2009). Penggunaan Serbuk Tulang Ayam Sebagai Penurun Intensitas Warna Air Gambut. Tesis. Sekolah Pasca sarjana.Universitas Sumatera Utara. Medan.

Fauziah, N. (2011). Pembuatan Arang Aktif Secara Lagsung dari Kulit Acasia mangium Wild dengan Aktivasi Fisika dan Aplikasinya Sebagai Adsorben. Skripsi. IPB. Bogor.

Gomez-Serrano, V., Pator-Villegas, J., PerezFlorindo, A, Duran-Valle, C. \& ValenzuelaCalahorro, C. (1996). FT-IR Study of Rockrose and of Char and Activated Carbon. Journal of Analytical and Applied Pyrolysis. 3: 71-80.

Keputusan Menteri Negara Lingkungan Hidup Nomor 202. (2004). Baku Mutu Air Limbah Bagi Usaha dan atau Kegiatan Pertambangan Bijih Emas dan atau Tembaga. Jakarta. 
Ooi, C.Y., Hamdi, M., \& Ramesh, S. (2007). Properties of hydroxypatite produced by annealing of bovine bone. Ceramics international 33,1171-1177.

Palar, H. (1994). Pencemaran dan Toksikologi Logam Berat. Rineka. Jakarta.

Prawirakusumo, S. \& Utomo, T. (1970). Pembuatan Karbon Aktif. Hasil Penelitian Lembaga Kimia Nasional. Lembaga Kimia Nasional. Bandung.

Jamilatun, S. \& Setyawan, M. (2014). Pembuatan Arang Aktif dari Tempurung Kelapa dan Aplikasinya untuk Penjernihan Asap Cair. Jurnal Spektrum Industri, 12 (1), 73-83.
Sontang, M., (2000). Optimasi hydroxyapatite dalam tulang sapi melalui proses sintering. Tesis, Universitas Indonesia. Depok.

Standar Nasional Indonesia. (1995). Arang Aktif Teknis (SNI 06-370-1995). Badan Standardisasi Nasional Indonesia. Jakarta.

Sukardjo. (2002). Kimia Fisika. Edisi Baru. Rineka Cipta, Jakarta.

Ward, A.G., \& Courts, A. (1977). The Science and Technology of Gelatin. Academic Press. London.

Wijayanti, R. (2009). Arang Aktif dari Ampas Tebu Sebagai Adsorben Pada Pemurnian Minyak Goreng Bekas. Skripsi. Institut Pertanian Bogor. Bogor. 